ABORIGINAL HISTORY 1978 2:2
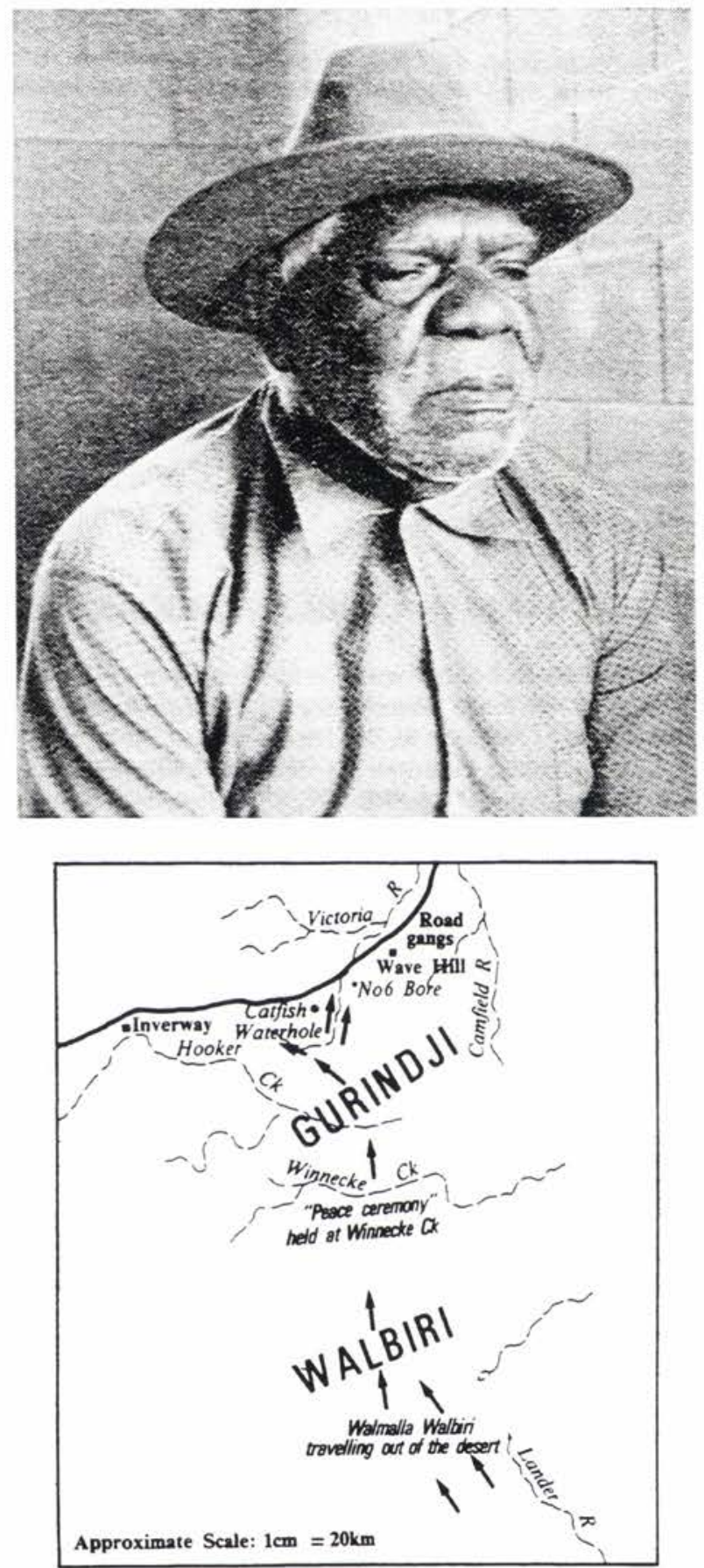

Top: Engineer Jack Japaljarri.

Bottom: Sketch map of the Wave Hill area. 


\title{
THE PRICE OF TOBACCO: THE JOURNEY OF THE WARLMALA TO WAVE HILL, 1928*
}

\author{
Peter Read and Engineer Jack Japaljarri
}

Engineer Jack Japaljarri is a Warlmala Warlpiri (Walbiri) whose country lies between Winnecke Creek and Hooker Creek in the Northern Territory. ${ }^{1}$ In about 1910 he was born in the desert. For some eighteen years he lived the life of his Warlpiri ancestors, interrupted by occasional meetings with itinerant white men. His hunter-gatherer existence, and that of the group of about fifty Warimala with whom he lived, was brought abruptly to an end in 1928. Towards May of that year, since the supply of tobacco and other provisions formerly provided by Europeans was no longer readily available, the Warlmala decided to travel to Wave Hill Station, where a supply was known to exist. By June the group had arrived at the station; by Christmas, according to Engineer Jack, most of them were working. He himself began work in a road gang. Later he became a steam and diesel mechanic, and continued working at Wave Hill until the war. In 1940 he joined the Army, and spent much of the next four years at the camp at Banka Banka. Demobilised in 1945, he was sent to help build the new Baptist settlement at Phillip Creek. In 1953 the site was abandoned, and the inhabitants moved to Warrabri, where Engineer Jack still lives.

The part of Engineer Jack's narration transcribed here concerns the period 1927. 28 , from the time shortly before the decision to visit Wave Hill was taken, to the outbreak of the Coniston killings in August 1928. In 1926-28 the Warlmala had met several wandering European bushmen. First mentioned was Joe Brown, a small-scale pastoralist famous for his bushcraft. Second was a miner whom Engineer Jack identifies as 'Mr Hamilton'. Hamilton wanted guides to take him into the Tanami and Granites goldfields, first discovered by the geologist Davidson in 1900 . It was through the economic relations with these two Europeans that the Warlmala desire for European commodities was implanted. When Engineer Jack's father and uncle returned from the Granites, the Warlmala were faced with the problem of how to acquire European tobacco. It was a problem which must have confronted many Aboriginal groups in areas where there was little permanent pastoral settlement. The Warlmala difficulty in visiting Wave Hill was that their route lay through Kurintji country. How much they knew of the country to the north is not clear. Trade amongst Warlpiri clans was not extensive. ${ }^{2}$ McCarthy suggests that such trade as did exist with the northern tribes was carried out by the eastern Warlpiri clans, and by the Warramunga. ${ }^{3}$ If the Warlmala traded infrequently with the Kurintji and Mutpara, they nevertheless must have had information about what was likely to be available at Wave Hill. In former times, Engineer Jack stresses, the Kurintji and Warlmala 'used to make a war'. The necessity now was to 'get friendly'.

* For linguistic advice I would like to thank Ian Green and Diane Bell, and for their comments on the manuscript as a whole $I$ am indebted to Jay Read and Jim Urry. This interview was recorded 3 April 1977 at Warrabri Settlement, during the collection of material for a forthcoming secondary school text, An Aboriginal oral history of the Northern Territory. The speakers were Engineer Jack Japaljarri and Blind Alec Jupurrula, interviewed by Peter Read. This tape and others referred to in the paper are held by the archives of the Australian Institute of Aboriginal Studies, Canberra.

1 Biographical information was collected in the same interview. Standard Waripiri orthography in use for the bilingual programme of the Yuendumu school, and with minor variations at the Lajamanu (Hooker Creek) school, is used throughout the paper.

McCarthy 1989:429, map 8. 
Engineer Jack describes two separate 'peace' ceremonies held before the Kurintji were satisfied. One was at a hill north of Hooker Creek, identified as Nyirriwiyat, and one was at the station itself. Both occasions were preceded by 'marching, Aboriginal way', and seem to have involved large-scale formal ceremonies. Presumably they were of the type witnessed by Spencer and Gillen in $1901 .^{4}$ At the conclusion of the first meeting the Kurintji (some of whom were bound for Inverway in search of tobacco) travelled northwards on the eastem side of the Victoria River. At Wave Hill the Warlmala arrival caused a mild commotion which is still remembered in the Territory. ${ }^{5}$ Tobacco was given to the visitors, who appear then to have retired for several miles. After a few days, the supply exhausted, they desired more tobacco. A decision was made to return to the station. The manager, McCugan, now demanded work in return for rations. The Warlmala were divided into four or five groups. Most of them began to 'cleanem road'. The Kurintji and Waripiri, traditional enemies, worked side by side in a white man's road gang.

Some weeks later news arrived from the south that the prospector Brooks had been murdered, and that the pastoralist Morton had been attacked. A police expedition was in pursuit of the culprits. Probably the newsbearers were Aboriginal refugees from the upper Lander, where the attack upon Morton was even then being avenged by the police. At this point in Engineer Jack's narrative, Blind Alec Jupurrula, who had remained silent, interrupted with the information that his aunt had been one of the newsbearers. His father, he said, had been shot by the police party on the Lander; his mother had escaped south-westwards to Mount Doreen Station, and his aunt had carried him in the opposite direction to Wave Hill. Engineer Jack later mentioned that the white overseer of the road gang had warned the Warlmala not to return to their own country while the police party remained in the region.

\section{Account of the journey of the Warlmala to Wave Hill by Engineer Jack Japaljarri}

\section{Q. Where were you before Wave Hill?}

In the desert.

Q. Why did you come out of the desert, to that Wave Hill Station?

$\mathrm{O} h$, we just bin living there, and plenty, oh, kang...wallaby, you know. Wallaby. Plenty good to live in the desert, plenty water too you know. The spring water, some spring water, some the soaks water. Live together... this way. This is grandfather bin live too. My grandfather, desert, still be 'live still. He, 'fore you people lived there, in the desert. Before the Wave Hill, you know.

Young feller...my father, he's [met] one white feller from Alice Springs. He should be come, he might be north of one Joe Brown. ${ }^{6}$ Well, Joe Brown got mob of horse. He go straight along Lander Creek, used to live there. He givit it tobacco...All right, we bin walk down before the - Old man, all bin there young feller, you know. Cookembat the whatsaname, you know wallaby. Big mob of wallaby that time, one bandicoot, anything, you know. Wild sugarbag. Bin live 'gether. All right, I bin losem my grandfather, in the desert. Well, it still-feller living together, my father. Big mob, you know, big mob of people. They bin cut out now. Some go this way live, and some go this way, north. 'We live this way, and people bin live there'. All right, it's my father bin move away, leave quick that way, you know. 'Well, what do we got to

5 Spencer 1928:325.

5 For example, in June 1977 the manager of the Vestey station Nutwood Downs was able to recount to $P$. Read most of the details of the Warlmala arrival.

6 Buchanan (1939:148) notes: "Joe Brown, the greatest bushman of this century in the North, led what was almost a hermit's life - that is, if one whose home is bounded by the extreme outposts of civilisation north, south, east and west in Northern Australia, can be called a hermit. He wandered between the upper Sturt and the Lander, and he discovered what is known as the J.B. Track from Tanami to Coniston'. 
do now? We'll have to look about for tobacco now'. Well we sit down first, and this he bin leavem, my father, desert.

Well one white feller bin come, big mob of cattle, you know...Mr Hamilton. And he got two old men, two boy, one Alyawarra, that one Warlpiri that, you know, Kaiditj that. He's got one woman, one woman there for Alyawarra. He takem that one. 'Oh, we'll go this way, and I'll show him where the Tanami, in the desert this way, big mob of camel'. And they all go live 'gether, in the middle you know, old man bin live, mob. He got three, ol' gooman, he got this four woman, this my father, but...big mob, my brothers, brother and sister, you know. All finish now. I'm by myself.

Well, we bin live 'gether, sit down there, good while, and my father bin go hunting, chasing with a one wild dog, wild dog and wild pussycat. That's him, he couldn't kill him, and sometimes that white feller bin killem behind. Mr Hamilton, he shootem there. All right, 'nother mob, big mob camel, two...horse and camel, changem round. Oh, we bin cut out now, all bin cut out runaway now, we bin run away too. Well, morning time all bin muster up again. We all frighten, you know. We run away for that white feller: 'Oh, what's the matter you-feller run away?'

The old man, Mr Hamilton, and 'Oh, don't run away. We'll give you bullock'. That meanem, he killem camel, see. Him killem camel, him not bullock. While him ridem him killem camel. That bullock that one, killem one open, cuttem now. This moming time. We living on that camel, everybody bin eatem. Good tucker now. They bin leavem, cuttembat now. Givit flour, flour and tobacco and tummyache everyone, just leavem. 'Right, I'll take a message, old man. You got to show me country'. 'Where country?' 'Show me this way'. All right, him bin Granite, Tanami. See how he got the map. 'I want to findem Tanami, and Granite'. This old man, 'All right'. It's my father bin say, 'You fellers sit down. I'll showem you country belonga this white feller'. All right. We bin sit down. Him killem camel. He'll shootembat that camel now. It's like, it's like a bullock too, you know. This old man bin there - that's his country too. That's belonga country me-feller, like. 'I Il showem you Tanami, and I'll leavem in the mid', - all his family, you know. Two feller bin go, old men, two old men from this country, belong to Peter father, you know, his two brothers. We callcm 'father' too, tribal law, you know.

They bin go now, right up longa Granite. There, all right, they givit. They givit tucker, everything. 'And two feller go back from here, but I gottem road now, findem. That's all right, you-feller bin showem me this Tanami, Granite and I gotta get rucker from the Hooker's Creek...you know' [said Hamilton]. That old man, two old man bin come back, right back. This one man bin come this way, 'nother old man bin come, 'All right', him bin say, old man bin there. 'Oh, we gotta go for tobacco now. Where you-feller got to go?'

'Oh, we go this way now, big mob. Big mob bin coming of them people, you know, Walmunpa and Warlpiri mix, you know, altogether. We bin going Winnecke Creek river, you know, the Winnecke Creek river, you know, it's that one from Hooker Creek'. We going big mob of soldiers, you know,...soldiers, Aboriginal way. Going to Kurintji we got to meet up the Kurintji people. Used to be, used to fight, Warlpiri and the Kurintji. All right, now going to Kurintji country. All right, we got to make a friend now, Kurintji. It's my father bin make a law: 'You can't fight', and my uncle, 'you can't fight'. We gotta, this time we makem friendly, we want to gettem longa tobacco, go longa tobacco, get it tobacco.

All right, right we bin go longa hill now. Climb up. Well, 'nother Kurintji bin sleep there, behind the hill, you know, big mob again. They bin make big camp. All right, they bin burnem bush fire, oh, they bin run away now. They bin findem. All right, one bloke we bin meetem, married man. Oh, white people no all about here, all there, people bin there. White soldier him there too ['there' - in the direction of Alice Springs]. All right, we got to makem meeting, talk about the meeting, you 
know, got to makem friendly. Right, all bin come, the Kurintji, Warlpiri and Kurintji mixem. All right, we bin come out now, marching, you know, Aboriginal way marching. We talkem Aboriginal marching first. All right, stand up one another, you know, showem one another. No, nothing, no woomera, nothing. All right, no trouble, nothing. Showem down. No white feller fighting - just Aboriginal way meet up. All right, one old man bin make a law: we gotta get on friendly now, none matter they bin fight before. All right, this time we'll be friendly.

All right, what you fellers got to, we bin camp here that days, in the bush, you know, right alonga Winnecke Creek, you know that big hill. You know, just that side from Hooker Creek. All right, they callem Jirpirli you know. Aboriginal callem Jirpirli. We bin live there, all come out now. 'All right, we'll camp there'. 'Fore light, man, woman, bin camp there, men, young feller bin camp there, you know, altogether. Singem all the way. Singem, you know, country. Singem country business you know. Right, first thing in the moming, first thing in the morning, they bin showem down: 'Right, where you got to go?', Kurintji bin there. 'I'm going to Wave Hill. I want to get to Wave Hill'. All right, Warlpiri bin there: 'Where you fellers going to go?' 'Go longa Inverway Station. They callem Ngangkuri, you know. And we get tobacco there'. 'Righto, we're going to shoot through, long whatsaname, Wave Hill. Go longa Catfish [Waterhole, on the Victoria,] , longa Nyirriwiyat, you know'. Where you bin go there, big mob. Wave Hill the first one, you know, people with the work. Go on, finish. Come out longa whatsaname from chasing bullock too, you know, lot of bullock. And we can't havem there now. And all bin travelling there. And Catfish. $O h$, that camp bin leave there, from $W$ ave Hill, and Inverway. And Kurintji bin travelling that side, you know, 'nother side. Waripiri bin travelling this side.

Q. That's towards Wave Hill?

Yeah. They callem Wave Hill now. We bin go longa Wave Hill now. And that mob bin go longa Inverway, you know. All right, Hamilton, that the whitefeller bin camping there, big mob, used ro be Aborigine too. Right, we bin travelling Inverway, longa whatsaname, Nyirriwiyat. Camp there, morning time. All right, this morning we go travelling, got to go longa Number Six there, Number Six Bore. Come out longa Wave Hill. New station Wave Hill, not that police station, but new station, this side one. All right, there's the big mob of Kurintji, Mutpara and Walmunpa mix. All bin live 'gether. 'Oh, the Warlpiri travelling!' and that, big mob, Warlpiri travelling. The first one we bin meet up Wave Hill now. All right, they bin come out, Warlpiri, now. He's my father bin come out. All right, uncle, my uncle bin come out. Oh, big mob, everywhere. They bin stand up now, he got trouble before - you know what they bin kill one another. They bin stand up one another, showem that.....No fight, no trouble, all right, no trouble. Stand up one another there, you know, big mob, you know. You know we can't makem fight now, finish. All right, they bin givit tobacco now.

Q. Who gave you tobacco? The white fellow at Wave Hill?

Whitefeller tobacco.

$Q$. What was his name?

McCugan...You know, used to be Tingal, Mr Coonachie, Mr Maurier. That's the manager, you know. Oh, old men, you now. That's the first one.

Q. So he gave you tobacco?

Yeah. He givit tobacco. All the Warlpiri coming up, come up. All right...Sometimes we givit job now, for work you know. All right, all right, all bin sit down three days, sit down three days. 'Oh, we'll have to go back first. We'll go back first. Get tobacco. We'll come back bye and bye'.

Big mob bin go back now, right back to long Wave Hill, Wave Hill new station. Come out long whatsaname, you know, camp yard, to long Nyirriwiyat. And I bin losem father mine....We bin go back now. I bin losem my father, friendly. And all bin go back, right back another people, you know, crying everything. We bin sorry, you 


\section{THE PRICE OF TOBACCO}

know. 'Now what are we going to do? We can't go back. Soon as you go back, we'll come back again'. 'All right, we'll go back into Wave Hill again. You know, we'll sit down 'bout there. We've got to givit job now, you-feller wantem Warlpiri got to cleanem road, you know.

Q. Oh, the road gang?

Road, you know. You know, used to pickem all the way rock, you know. All right, they bin puttem three lot: 'nother mob that way, 'nother mob that way. Nother mob that way they bin puttem. 'Nother mob round station, you know. We bin working now working together now, Kurintji and Warlpiri. All right, working now, right up the Christmas. Right, before Christmas we bin hearem trouble. ${ }^{7}$ Trouble going on longa Lander. They bin startem the war. Aborigine and whitefeller bin startem war. This way I bin longa Wave Hill now.

Q. You heard about it at Wave Hill?

Yeah. That's the first one, ain't it? We bin longa that way now. We bin hearem that way. And they bin kill one another, old man bin killem one another, longa that old Boomerang Hole. They bin make a war. Hanson Creek. We bin first one from desert. We bin first one from desert. We bin first one go from desert. We bin come along Wave Hill first.

Engineer Jack's story is particularly interesting as an account of what appears to have been a voluntary decision to visit a cattle station to procure supplies. Of the many aspects of the narrative which invite analysis, two deserve comment: Engineer Jack's cited reason for the decision to visit Wave Hill; and the contrast between the historian's and the Aboriginal evaluation of the critical period between life in the desert, the hunter-gatherer existence, and permanent station life.

Engineer Jack makes no mention of the severe drought, documented in European sources, which affected the pastoral industry in the whole of Central Australia from 1924 to 1929; in fact he later denied that shortage of food or water was a factor in the Warlmala decision. It has been assumed by some European commentators that the drought must have been of critical importance to the desert tribes. J.W. Bleakley, discussing the conflict between station and bush Aborigines in time of drought, noted:

That the position as regards water has in some places become acute may be seen

from the fact that a large party of Warramulla blacks, a wild desert tribe, were seen at Wave Hill station, where they had come, bringing their women and children, which in itself was significant, because the waterholes had dried up. ${ }^{8}$

Meggitt takes the same view, slightly exaggerating Bleakley's remarks:

Some walked because of the drought to Birrindudu and Gordon Downs Stations, others crossed Hooker Creek into Wave Hill, where Bleakley (1928) remarked on the arrival of one party of Walmalla who were almost starving.

It is possible that an eighteen year old lad may have been confused as to the real motives of the Wave Hill visit, but it is unlikely that a drought severe enough to cause a large number of bush people to visit a station in search of supplies has been so completely forgotten or suppressed. Other men interviewed on the Coniston massacre itself have stated that there was no real shortage of water for the Warlpiri in the years before the shooting. ${ }^{\circ}$ That there was what the Europeans considered a serious

7 The orientation of most of the northem Waripiri in speaking of the Coniston massacre is directed at the attack on Nugget Morton on the upper Lander River, 28 August 1928. However, the incident which triggered the sequence of events which led to the murder of probably over one hundred Aborigines was the spearing of Fred Brooks, at Brooks Soak, on 7 August, some $150 \mathrm{~km}$. farther south of the place where Morton was attacked.

Bleakley 1928:31.

10 Meggitt 1962:24.

For example, Tim Japangardi, interviewed by P. Read, Yuendumu, 9 August 1977, tape 49:1. 
drought in the middle 1920s cannot be doubted. The Government Resident specifically mentioned the shortage of water or feed in the Annual Reports of 1924,1925 , 1926 , and 1928. ${ }^{11}$ It was possible that in a time of severe drought the desert tribes might seek relief outside their own country. Tindale noted that in a bad year the Nara in the Western Desert had been 'driven out of their usual territory by lack of rain... and because it was in another tribe's territory, only older persons had ever seen it. In this case the reception was friendly'. ${ }^{2}$ Engineer Jack was quite definite, though, and in the absence of hard evidence to the contrary, his account of the Warlmala motive must be accepted. It seems that Bleakley's conclusion that a search for water or food was the sole reason for the Warlmala arrival was almost certainly wrong. The claim that tobacco was the primary factor in the visit has support elsewhere. Many Aborigines have cited the desire for tobacco as the reason why they, or their parents, visited cattle stations. ${ }^{3}$ This was the pattern, for instance, at Bathurst Island Mission, where the Government Resident reported in 1923: 'after a few months at the station they feel the call of the bush and must go away for a time... Their supply of tobacco soon runs short, and they return to the station for another period. They are continually on the go thus to and from the bush'. ${ }^{14}$ It seems to have been a fairly common practice in the settled areas of the Northern Territory for bush people to wander in and out of stations, visiting relatives, collecting supplies, for years, or even decades. Warlpiri men told Meggitt that they were content to maintain this pattern of sporadic contact with Europeans indefinitely, so long as no pressure was put upon them by pastoralists, missionaries or welfare authorities to abandon nomadic life. ${ }^{15}$ It is probable that the fifty Warlmala who visited Wave Hill in search of tobacco would have maintained their independence by returning to the station only occasionally, to deal with relatives rather than with the station management. But the Coniston massacre intervened, the Warlmala could not return to their country, and the more usual pattern of a gradual lessening of independence over ten or fifteen years was telescoped into a few months. Whatever their original intentions, two months after leaving the desert, many of the Warlmala were enduring conditions in a road gang little short of slavery. ${ }^{16}$ It may be that the Warlmala expected no better treatment at Wave Hill. The station enjoyed a reputation for

11 Northern Territory, Reports: $1924: 3 ; 1925: 3 ; 1936: 5 ; 1928: 5$.

12 Tindale 1974:79.

13 For example, Warrakj No. 1, translator Bilu, interviewed by P. Read, Elcho Island, 10 May 1977, tape 28:1; Ninawunda Jerakba, translator Ivan Mamarika, interviewed by P. Read, Groote Eylandt, 5 May 1977, tape 20:1.

14 Northern Territory, Report 1924:25.

15 Meggitt 1962:23-24. That this pattern of sporadic contact lasted into the 1930s and 1940s was confirmed by Johnny Nelson Jupurnula (interviewed by P. Read, Warrabri, 18 April 1977, tape 8:2); and Jimmy Hooker Creek Jungarrayi (interviewed by P. Read, Willowra, 13 August 1977, tape 59:2). Jimmy Jungarrayi stated that following the Coniston massacre, his father remained on the fringes of Anningie and Willowra Stations for the rest of his life, while Jimmy Jungarrayi himself began station work at Gordon Downs.

16 It is probable that the Warlmala would in any case have begun work for the station, but that they would have left their employment within two or three weeks is also probable. That conditions of near slavery prevailed at Wave Hill can be inferred from the comments of Matthew Thomas, in charge of a road gang between Wave Hill and Inverway, who reported to the Northern Standard, 20 August 1937:

For ten weeks I was in charge of a gang of natives repairing the road for over 100 miles between Wave Hill and Inverway Station. My gang consisted of three boys and seven lubras ...The native wages were: beef, damper, tea, sugar, with three sticks of dried up nicky tobacco for the boys, and two sticks for each lubra per week. Trousers, shirts and boots were sent out for the boys, but nothing for the lubras, who had to make dresses from flour bags to cover their naked bodies. They worked harder and longer hours than the bucks. That the natives were working in slave conditions cannot be disputed, also they worked under appalling conditions with the sanction and approval of the Minister of Territory Affairs and Chief Protector of Aboriginals. 


\section{THE PRICE OF TOBACCO}

hospitality among European travellers, but there seems to have been no reason for the Warlmala to have expected anything but a cool reception. ${ }^{17}$ A white informant stated that Paddy Cahill, the manager of Oenpelli Station, had been called over in about 1924 to deal with cattle killers. He shot over thirty bush people. ${ }^{18}$

There is a temptation for the historian to assume in these events an inherent significance upon which whites and blacks must agree. In his narration, though, Engineer Jack seemed to regard the events of 1928 as more a good story, less a fundamental discontinuity in his life. An Aboriginal interpretation of the significance of the Wave Hill visit may be at considerable variance with the European estimation. There are at least two reasons for these divergent interpretations, both of which are relevant to the study of Aboriginal history. The first is that if too much attention is paid to the consequences of an event, rather than to the processes by which an event takes place, a conscious causality may be inferred which was not in fact present. Thus a short view of the Warlmala arrival may suggest that at some point a conscious decision must have been taken, not only to visit, but also to remain at the station, to set aside to some degree their former way of life, and to fall in with the ruies of life dictated by the management.

Engineer Jack's story shows clearly that no decision to remain at the station was made. The series of steps by which the Warlmaia came to accept the European sway were small, and for the most part unplanned. By the end of the Coniston shooting there may have been as yet little sense among the old people that any part of the old pattern of life had been compromised, replaced or lost. Frequently they must have speculated whether it was safe to return to the desert. At the end of the first five years of station life, those who had been toddlers in 1928 would have lacked knowledge of a desert life. Until the War it is likely that within the Warlmala station community two different concepts of the meaning of station life existed side by side. To the old people, station life may still have seemed temporary - soon a permanent return would be made to the homeland; but those less than fifreen years old knew no other permanent life than the station and stock camps of Wave Hill.

Research into Aboriginal history in the Northern Territory suggests that a good deal of what can appear to have been a conscious choice to abandon desert homelands would be better described as accidental. Thus the Daly River tribes which Stanner describes as having been drawn towards European settlements in the 1920s and 1930s in pursuit of European goods originally may have come solely to visit. ${ }^{19}$ Perhaps the Kamor and Yunggor always intended to return but for various reasons their intention was postponed, year after year, until a return became a practical impossibility. Elsewhere, too, research may show that many of the permanent station communities came to stay accidentally. Bobbie Hardy, for instance, says of the Barkindji, 'the seductive allure of European goods was a potent factor behind their submission'. 20 It may be that the young men had no conscious intention of attach. ing themselves, still less submitting, to the squatters. But life was lived from day to day: novelty bred a habit, and habit bred a dependence into which the next generation, which knew no other relationship, was born. ${ }^{21}$

17 For example, the pleasant week spent at Wave Hill by Michael Terry (1926:108-113).

18 Personal communication, Dr Stephen Harris, Darwin, 12 March 1978.

19 Stanner 1960:75.

20 Hardy 1976:79.

21 I offer here a suggestion as to why some station communities came to be permanent. To the larger question of how and why the Northern Territory station communities grew and stabilised there is no simple answer. Quite a different explanation was offered by Mr Alec Wilson (interviewed by P. Read, Mount Doreen, 7 August 1977), who suggested that the station communities which be knew had been begun by young men who, after seizing another's promised bride, had run to the nearby station for protection; their children formed the basis of the station community. 
The second reason for Engineer Jack's variant interpretation is that he may consider that his fundamental life-spring was not upset to any great extent by station life. Ritual life at Warrabri is probably at least as vigorous as it is in any of the other large settlements, and Engineer Jack is a most important Warlpiri figure. Following the interview, it appeared in further discussions over several days that he considered Warlpiri culture to have lost nothing since 1928 . He could scarcely believe that some Aborigines elsewhere in Australia can no longer speak their native language. His surprise may point to the difficulties of interpreting cross-cultural history. The historical analysis of an event by the conquerors may not necessarily be that of the conquered. To the European historian, Engineer Jack describes a process whereby a nomadic people, within two or three months, came under the yoke of a sedentary and separate culture. Engineer Jack seems to regard the process as an important phase of his life, not a sudden transformation. The ritual life of the Warlpiri, in his opinion, has transcended the abandonment of nomadic life. The inner life has survived: the continuance of Warlpiri culture has been assured.

DEPARTMENT OF EDUCATION, N.T. AND WARRABRI SETTLEMENT, N.T.

\section{BIBLIOGRAPHY}

Bleakley, J.W. The Aboriginals and half-castes of Central Australin and North Australia. (Parliamentary Papers. No. 21). Melboume, 1929.

Buchanan, Gordon. Packhorse and waterhole: with the first overlanders to the Kimberleys. Sydney, 1933.

Hardy, Bobbie. Lament for the Barkindji: the vanished tribes of the Darling River Region. Adelaide, 1976.

McCarthy, F.D. "Trade" in Aboriginal Australia, and "trade" relationships with Torres Strait, New Guinea and Malaya', Oceonia, 9(4), 1939:405-435; 10(1), 1939:80-104; 10(2), 1939:171-195.

Meggitt, M.J. Desert people: a study of the Walbiri Aborigines of central Australia. Sydney, 1962.

Northern Territory. Report of Administrator for the year ended 1923. Melbourne, 1924.

Northem Territory. Report of Administrator for the year ended 1924. Melbourne, 1925.

Northern Territory. Report of Administrator for the yeat ended 1925. Melbourne, 1926.

Northern Territory. Report of the Acting Administrator for the year ended 1926. Melboume, 1927.

Northem Territory. Report on the administration of the Northern Territory for the year ended 1928. Canberra, 1929.

Spencer, W.B. Wanderings in wild Australia. (vol 1). London, 1928.

Stanner, W.E.H. 'Durmugam: a Nangiomeri', in Casagrande J.B. ed. In the company of man: twenty portraits by anthropologists. New York, 1960.

Terry, Michael. Through a lend of promise, with gur, car and camere in the heart of northern Australia. London, 1927.

Tindale, N.B. Aboriginal tribes of Australia. Canberra, 1974. 